\title{
SYSTEMATIZATION OF APPROACHES TO THE DEVELOPMENT OF QUALITY SYSTEMS INDICATORS AND NETWORK SERVICES RELIABILITY
}

DOI: $|0.36724 / 2072-8735-202|-|5-5-58-6|$

Manuscript received 24 March 2021;

Accepted 20 April 2021

Zain-aalabdain Al-namer, Moscow Technical University of Communications and Informatics, Moscow, Russia, zainalnamer29@gmail.com

Keywords: Quality of Service, Network

Communication General User, Latency, Jitter, Packet loss, IP Multimedia Subsystem, Long Term Evolution, High Speed Packet Access

Для цитирования:

Заин-аалабдайн Аль-Намер Систематизация подходов к разработке показателей систем качества и надежности сетевых услуг // T-Comm: Телекоммуникации и транспорт. 202I. Том I5. №5. С. 58-6I.

For citation:

Zain-aalabdain Al-namer (202I) Systematization of approaches to the development of quality systems indicators and network services reliability. T-Comm, vol. I5, no.5, Pp. 58-6I. (in Russian)

Over a long period of development of the network communication general user (NCGU), various models have been developed, focused on the service of voice traffic. In the next generation NGN heterogeneous communication network, voice traffic service has become one of the applications. This application was subject to stringent timing requirements (latency and loss). Further development took place to develop new applications that impose even more severe service requirements. Such applications have had a significant impact on the requirements and timing of next generation communications networks. In this regard, it was proposed in various recommendations to distinguish networks that provide services with strict requirements for time parameters into a new class of networks and call them networks with low and ultra-low delays. 


\section{Stage evolution of requirements for quality of service} in communication networks

The design and planning of the public telephone network (PTN) using analog technologies was carried out on the basis of models from queuing systems (QS), as a rule, losses or failures using the first Erlang formula in the calculation [3].

At the same time, the admissible probability of losing calls from their end to end was normalized within ( $\left.(2-50) \cdot 10^{-3}\right)$. For example 5\% for city telephone networks [4]. The transition of the public telephone network to digital in terms of the requirements for the parameters of quality of service did not introduce new changes, since the structure of the network remained homogeneous. [5].

The development of the concept of a next generation communication network has led not only to the replacement of circuit switching technology with packet switching [2], [7], [6], but also to the fact that the network structure has become heterogeneous with different sets of applications requiring different services by class of service ( QoS - Quality of Service) [1]. Since the user of most communication services is a person, in order to adequately determine the requirements for the parameters characterizing QoS in recent years, another metric was introduced - the quality of perception (QoE - Quality of Experience), which determines the subjective assessment of the service by the user, for example, the quality of perception of video transmission [12][13]. The main focus of this chapter is on a new class of networks - low latency networks, therefore, below we will take a closer look at the QoS characteristics that are proposed in Recommendation Y.1541 of the International Telecommunication Union (ITU-T) Telecommunication Standardization Sector. Recommendation ITU.E.800, Quality of service is defined as the cumulative effect of service performance that determines the degree of user satisfaction.

Recommendation G1000, Separates service performance into functional components and links them to network performance as defined in a set of recommendations. I.350, Y.1540 and Y1541 .ITU Recommendation G.1000 defines the structure of the relationship between performance (performance, reliability, loss, latency, etc.) and network performance

ITU Recommendation G.1010 contains end-user-specific application requirements specifications. [8][9][10].

In 2002, MES-T developed two international standards that meet the first stage of solving the problem of QoS provision. ITU Recommendation Y.1540 [38] describes standard network characteristics for packet transmission over networks. ITU Recommendation Y.1541 [12][1] defines norms for parameters defined in ITU Recommendation Y.1540. In addition, ITU Recommendation Y.1541 specifies six application-specific QoS classes.

\section{New types of traffic and tightening requirements for latency}

In recent years, new applications have been developed and new types of traffic have emerged, requiring tightening of latency standards. The table shows the requirements of 3GPP [14] to the average delay and packet loss rate for various types of traffic transmitted with different priorities in modern mobile communication systems with the implementation of the IMS (IP Multimedia Subsystem) [15].
Table 1

Delay and Loss Requirements (3GPP, TS 23.203)

\begin{tabular}{|c|c|c|c|c|}
\hline № & Priority & Delay & PacketLoss & Application \\
\hline 1 & 0. & $60 \mathrm{MS}$ & $1 \times 10^{-6}$ & $\begin{array}{l}\text { Mission Critical delay } \\
\text { sensitive signaling } \\
\text { (e.g., MCPTT signaling, } \\
\text { MCVideo signaling) }\end{array}$ \\
\hline 2 & 0. & $75 \mathrm{MS}$ & $1 \times 10^{-2}$ & $\begin{array}{c}\text { Mission Critical user } \\
\text { plane Push To Talk voice } \\
\text { (e.g., MCPTT) }\end{array}$ \\
\hline 3 & 1 & $100 \mathrm{MS}$ & $1 \times 10^{-6}$ & Signaling IMS \\
\hline 4 & 1. & $10 \mathrm{MS}$ & $1 \times 10^{-3}$ & $\begin{array}{c}\text { Mission Critical Video } \\
\text { user plane }\end{array}$ \\
\hline 5 & 1. & $10 \mathrm{MS}$ & $1 \times 10^{-4}$ & $\begin{array}{l}\text { Discrete Automation } \\
\text { ("small packets") }\end{array}$ \\
\hline 6 & 2 & $100 \mathrm{MS}$ & $1 \times 10^{-2}$ & VoIP \\
\hline 7 & 2 & $100 \mathrm{MS}$ & $1 \times 10^{-2}$ & $\begin{array}{l}\text { Non-Mission-Critical user } \\
\text { plane Push To Talk voice }\end{array}$ \\
\hline 8 & 2. & $5 \mathrm{MS}$ & $1 \times 10^{-5}$ & Distribution- high voltage \\
\hline 9 & 2. & $10 \mathrm{MS}$ & $1 \times 10^{-4}$ & $\begin{array}{l}\text { Discrete Automation } \\
\text { ("big packets") }\end{array}$ \\
\hline 10 & 2 & $30 \mathrm{MS}$ & $1 \times 10^{-5}$ & $\begin{array}{c}\text { Intelligent Transport } \\
\text { Systems }\end{array}$ \\
\hline 11 & & $50 \mathrm{MS}$ & $1 \times 10^{-3}$ & $\begin{array}{c}\text { Real Time Gaming, V2X } \\
\text { messages } \\
\text { Electricity distribution - } \\
\text { medium voltage }\end{array}$ \\
\hline 12 & & $150 \mathrm{MS}$ & $1 \times 10^{-3}$ & $\begin{array}{c}\text { Conversation video } \\
\text { (Live streaming) }\end{array}$ \\
\hline 13 & & $300 \mathrm{MS}$ & $1 \times 10^{-6}$ & $\begin{array}{l}\text { Non-Conversational } \\
\text { Video (Buffered } \\
\text { Streaming) }\end{array}$ \\
\hline 14 & 5 & $200 \mathrm{MS}$ & $1 \times 10^{-6}$ & Mission Critical Data \\
\hline \multirow[t]{5}{*}{15} & \multirow[t]{5}{*}{5} & $150 \mathrm{MS}$ & $1 \times 10^{-6}$ & \multirow[t]{5}{*}{ "Live" Uplink streaming } \\
\hline & & $300 \mathrm{MS}$ & $1 \times 10^{-4}$ & \\
\hline & & $300 \mathrm{MS}$ & $1 \times 10^{-8}$ & \\
\hline & & $500 \mathrm{MS}$ & $1 \times 10^{-8}$ & \\
\hline & & $500 \mathrm{MS}$ & $1 \times 10^{-4}$ & \\
\hline 16 & & $300 \mathrm{MS}$ & $1 \times 10^{-6}$ & $\begin{array}{c}\text { Video (Buffered } \\
\text { Streaming) } \\
\text { TCP-based (e.g., www, } \\
\text { e-mail, chat, ftp, p2p file } \\
\text { sharing, progressive } \\
\text { video, etc.) }\end{array}$ \\
\hline 17 & 6 & $50 \mathrm{MS}$ & $1 \times 10^{-2}$ & V2X message \\
\hline 18 & 6 & $10 \mathrm{MS}$ & $1 \times 10^{-6}$ & $\begin{array}{l}\text { Low latency eMBB appli- } \\
\text { cations (TCP/UDP-based); } \\
\text { Augmented reality }\end{array}$ \\
\hline 19 & & $100 \mathrm{MS}$ & $1 \times 10^{-3}$ & $\begin{array}{c}\text { Voice, Video } \\
\text { (Live Streaming) } \\
\text { Interactive Gaming }\end{array}$ \\
\hline 20 & & $300 \mathrm{MS}$ & $1 \times 10^{-6}$ & $\begin{array}{c}\text { Video (Buffered } \\
\text { Streaming) TCP-based }\end{array}$ \\
\hline 21 & & $300 \mathrm{MS}$ & $1 \times 10^{-6}$ & $\begin{array}{c}\text { Video (Buffered } \\
\text { Streaming) TCP-based }\end{array}$ \\
\hline
\end{tabular}

Table 1 provides the requirements for the use of long-term evolution of LTE (Long Term Evolution) in communication networks [16]. 
In such networks, measures have already been taken to ensure the average delay required for a real-time game of $50 \mathrm{~ms}$ and a fraction of the loss of $1 \times 10-3$ [13], [17]. This value is half the latency requirement for VoIP transmission and three times less than the latency requirement for video calls. At the same time, it is required to significantly increase the data transfer rate at the user access level.

In accordance with [18], the change in packet delivery delay requirements in 3GPP standardized systems was as follows. In 3G communication systems implemented in accordance with the 1999 3GPP standards, the average delay was 68ms. The introduction of HSPA (High Speed Packet Access) technology allowed reducing the average latency in $3 G$ systems to 51ms, and with the further development of this technology (up to HSPA +), the latency was reduced to less than 30ms. Fundamental changes in the amount of delay in cellular mobile communication systems have occurred with the introduction of LTE. When servicing traffic on a schedule, it was possible to reduce the latency to $20 \mathrm{~ms}$, and when booking with preliminary allocation of resources - to $15 \mathrm{~ms}$.

Changes in the requirements for the delivery time of a package for modern communication networks today are not limited to the emergence of a real-time game service. Over the past few years, there has been a significant increase in attention to eHealth systems [18]. The e-Health system is a general approach to informatization, in the field of medicine and health services. It provides for the use of modern communication networks with a sufficiently high level of development to provide information transfer services between medical devices. At present, machine-tomachine (M2M) networks are considered as such networks [19]. As can be seen from Table 2.4 (it is necessary to draw up a table with the quality requirement) among the quality of service parameters for new services of the e-Health system, the requirement for latency values has increased to the level of $10 \mathrm{~ms}$. It should be noted that in modern conditions it is very difficult to provide a delay of $10 \mathrm{~ms}$ even in megabit networks, which will be proved in the next section of this work.

Despite the successes, in the design and development of the 4th generation (4G) cellular network. The trend in the global communications market introduces complex requirements that remind us of the need for a $5 \mathrm{G}$ mobile network. The technical characteristics of the generation of mobile networks (5G technology) for IMT-2020 were announced in the draft report of the International Telecommunication Union (ITU), [19], downlink bandwidth - 20 Gbps, uplink bandwidth - 10 Gbps, target values for user data rate in urban environments eMBB. Downlink user data rate $100 \mathrm{Mbit} / \mathrm{s}$, uplink user data rate $50 \mathrm{Mbit} / \mathrm{s}$, minimum requirements for autonomous operation of machine terminals without recharging the battery - for 10 years, minimum require- ments for user latency (4ms for eMBB, 1ms for URLLC), the minimum requirement for the control plane delay is $20 \mathrm{~ms}$, an even lower control plane delay of $10 \mathrm{~ms}$ is possible.

\section{References}

1. ITU-T Recommendation Y.1541. Network Performance Objectives for IP-Based Services. May 2002.

2. A. E. Kucheryavy, A. L. Tsuprikov (2006). Next generation communication networks. Moscow: Central Scientific Research Institute of Communications (TsNIIS). 278 p.

3. B. S. Livshits, A. P. Pshenichnikov, A. D. Kharkevich (1979). Teletraffic theory. Moscow: Communication. 224 p.

4. I.M. Zhdanov, Ye.I. Kucheery (1972). Construction of urban telephone networks. Moscow: Communication. $134 \mathrm{p}$.

5. A. N. Golubev, A. E. Kucheryavy, A. S. (1997). Mikov Switching systems at the end of the XX - beginning of the XXI century. Problems of development, implementation and operation of digital switching systems. Seminar RNTORES. Perm, April 21-23. P. 6.

6. Recommendation ITU - T. Y. 2021. IMS for Next Generation Network. Geneva. September, 2006. 20 p.

7. Recommendation ITU - T. Y. 2012. Functional requirements and architecture of next generation networks. Geneva. April, 2010. $96 \mathrm{p}$.

8. McDysan (2000). QoS and Traffic Management in IP and ATM Networks. McGraw-Hill.

9. E.A. Curly (2004). Traffic management and quality of service on the Internet. St. Petersburg, Science and Technology.

10. R. Koch, S.G. Yanovsky (2001). Evolution and Convergence in Telecommunications. Moscow: Radio and Communication.

11. ITU-T Recommendation Y.1540. IP Packet Transfer and Availability Performance Parameters. December 2002.

12. Zain-aalabdain Al-namer (2020). Rationing the main parameters of the Quality of Network services. T-Comm. Vol. 14. No.11. P. 72-76. (in Russian)

13. 3GPP TS 23.203. V 16.2.0, Technical Specification. 12, 2019. 263 p.

14. G.G. Yanovskiy (2006). IP Multimedia subsystem: principles, standards and architecture. Bulletin of communications. No. 3. P. 71-76.

15. A. E. Ryzhkov, M. A. Sivers, V. O. Vorobiev, A. S. Gusarov, A. S. Slyshkov, R. V. Shunkov (2012). 4G radio access systems and networks: LTE, WiMAX. SPb.: Link. 268 p.

16. Y. Koucheryavy (2012). Wireless Technologies for IoT: M2M, 3GPP, EE and Cooperative. SPb.: SUT. October 2012. 141 p.

17. ITU Technology Watch Report. E-health Standards and Interoperability. Geneva. April, 2012. 20 p.

18. S. Andreev, O. Galinina, Y. Koucheryavy (2011). Energyefficient client relay scheme for machine-to-machine communication. Global Telecommunications Conference (GLOBECOM 2011), Proceedings, Houston, Texas, USA. 5-9 December 2011. P. 1-5.

19. Source: Document 5D/TEMP/300(Rev.1). Minimum requirements related to technical performance for IMT-2020 radio interface(s). ITU-R, Geneva. 22 February 2017. 


\title{
СИСТЕМАТИЗАЦИЯ ПОДХОДОВ К РАЗРАБОТКЕ ПОКАЗАТЕЛЕЙ СИСТЕМ КАЧЕСТВА И НАДЕЖНОСТИ СЕТЕВЫХ УСЛУГ
}

\author{
Заин-аалабдайн Аль-Намер, Московский технический университет связи и информатики, Москва, Россия, \\ zainalnamer29@gmail.com
}

\section{Аннотация}

На протяжении длительного периода развития сети связи общего пользователя (Network Communication General User) (CCOП) были разработаны разные модели, ориентированы на обслуживание речевого трафика. В гетерогенной сети связи следующего поколения с коммутацией пакетов NGN ,услуга передачи речевого трафика стал одним из приложений. К данному приложению предъявили строгие требования по временным параметрам (задержка и потери). Далее происходило развитие до разработки новых приложений, которые предъявляют еще более жестокие требования к обслуживанию. Такие приложения оказали значительное влияние на требования и временные характеристики сетей связи следующего поколения. В связи с этим предлагалось в разных рекомендациях выделить сети, предоставляющие услуги с жесткими требованиями к временным параметрам в новый класс сетей и назвать их сетями с малыми и ультрамалыми задержками.

Ключевые слова: качество обслуживания, сети связи общего пользователя, задержка, потеря пакетов, мультимедийной подсистемы IMS, сеть связи длительной эволюции LTE, технологии высокоскоростного доступа HSPA.

\section{Литература}

I. ITU-T Recommendation Y.I54I. Network Performance Objectives for IP-Based Services. May 2002.

2. Kucheryavy A.E., Tsuprikov A.L. Next generation communication networks. M.: Central Scientific Research Institute of Communications (TsNIIS), 2006. 278 p.

3. Livshits B.S., Pshenichnikov A.P., Kharkevich A.D. Teletraffic theory. M.: Communication, 1979. 224 p.

4. Zhdanov I.M., Kucheery Ye.I. Construction of urban telephone networks. M.: Communication, 1972.134 p.

5. Golubev A.N., Kucheryavy A.E., Mikov A.S. Switching systems at the end of the XX - beginning of the XXI century. Problems of development, implementation and operation of digital switching systems // Seminar RNTORES. Perm, April 21-23, 1997. P. 6.

6. Recommendation ITU-T. Y. 2021. IMS for Next Generation Network. Geneva. September, 2006. 20 p.

7. Recommendation ITU-T. Y. 20I2. Functional requirements and architecture of next gen-eration networks. Geneva. April, 2010.96 p.

8. McDysan. QoS and Traffic Management in IP and ATM Networks // McGraw-Hill. 2000.

9. Curly E.A. Traffic management and quality of service on the Internet // St. Petersburg: Science and Technology. 2004.

10. Koch R., Yanovsky S.G. Evolution and Convergence in Telecommunications // M.: Radio and Communication. 2001.

II. ITU-T Recommendation Y.I540. IP Packet Transfer and Availability Performance Parameters // December 2002.

12. Zain-aalabdain Al-namer. Rationing the main parameters of the Quality of Network services. Т-Сотm: Телекоммуникации и транспорт, 2020. Том 14. №II. C. 72-76.

13. 3GPP TS 23.203. V 16.2.0, Technical Specification. 12, 2019. 263 p.

14. Yanovskiy G.G. IP Multimedia subsystem: principles, standards and architecture // Bulletin of communications. 2006. No. 3. P. 7I-76.

15. Ryzhkov A.E., Sivers M.A., Vorobiev V.O., Gusarov A.S., Slyshkov A.S., Shunkov R.V. 4G radio access systems and networks: LTE, WiMAX SPb.: Link, 20I2. 268 P.

16. Koucheryavy Y. Wireless Technologies for IoT: M2M, 3GPP, EE and Cooperative. SPb.: SUT. October 20I2. 141 p.

17. ITU Technology Watch Report. E-health Standards and Interoperability. Geneva. April, 20I2. 20 p.

18. Andreev S., Galinina O., Koucheryavy Y. Energy-efficient client relay scheme for machine-to-machine communication // Global Telecommunications Conference (GLOBECOM 20II), Proceedings, Houston, Texas, USA. 5-9 December 20II. P. I-5.

19. Source: Document 5D/TEMP/300(Rev.I). Minimum requirements related to technical performance for IMT-2020 radio interface(s). ITU-R, Geneva. 22 February 2017. 